\title{
外因性メラトニンの抗腫瘍効果に及ぼす 投薬時刻の影響
}

$\begin{array}{lllllll}\text { 牛之演 風 見* } & \text { 赤 木 貴 則* } & \text { 大 } & \text { 茂 弘* } \\ \text { 池 未 祥 子* } & \text { 湯 川 } & \text { 榮 二* } & \text { 樋 口 } & \text { 駿* }\end{array}$

\section{【目 的】}

生体には様々な日周リズムが存在し，これ らを考慮した薬物投与によって有害反応の軽 減や薬理効果の向上を導けることが多くの薬 物で報告されている 1)。一方，いくつかの薬 物が生体リズムを破綻させ，心身機能に悪影 響を及ぼすことも示唆されている 2). 外因性 メラトニン（MLT）は様々な作用を示す薬物 である。このうち抗腫瘍効果は，骨髄抑制な どの重篤な副作用のない抗腫瘍薬として臨床 試験が行われるなど期待されているが，投薬 時刻の影響については不明である。また， MLT は概日リズムの位相を変化させる作用 をもつために, 欧米では生体リズム調整薬と して市販されているが，投薬方法によっては 生体リズム障害を惹起する危険性が考えられ る. そこで本研究では, 抗腫瘍効果増強・生 体リズム障害回避を目的として, 外因性 MLT の抗腫瘍効果および生体リズム変容作用に及 ぼす投薬時刻の影響について検討した.さら に，これらの機序に関して薬力学的側面およ び薬物動態学的側面から検討を加えた。

\section{【方 法】}

実鈳動物：自由搷食攝水, 明暗周期（明期： 07:00-19:00) 条件下で 2 週間飼育した 5 週齢 ICR 雄性マウスを使用した. 腫㾇径測定：footpad にマウス肉腫細胞 sarcoma 180(S180)を移植し，翌日より MLT

(1mg/kg, i.p.) を 07:00, 13:00, 19:00 およ び 01:00のいずれかに連日投薬した。 8 日目 にDigimatic Caliper を用いて腫瘍径を測定 し, MLT の抗腫瘍効果に及ぼす投薬時刻の影 響を検討した。腫瘍推定重量は以下の式で算 出した。

腫瘍推定重量 $=($ 長径 $) \times(\text { 短径 })^{2} / 2$

行動量測定: 13:00, 01:00 のいずれかに MLT $(1 \mathrm{mg} / \mathrm{kg}$, i.p. $)$ を連日投薬し, 行動量を自動 運動解析装置( scanet SV-10)で経時的に測 定した.

MLTレセプター結合量 : 07:00, 13:00, 19:00 および 01:00 のいずれかに腫瘍細胞および suprachiasmatic nuclei (SCN)を採取し, $\left.{ }^{[3} \mathrm{H}\right]$ melatonin を用いて MLT レセプター機 能を測定した。

薬物動態: MLT (1mg/kg, i.p.)を 07:00, 13:00, 19:00 および 01:00 のいずれかに投薬後, 経 時的に採血を行い, 血中 MLT 濃度を HPLC 法にて測定した。薬物動態值は MOMENT 解 析法で算出した. また, 投薬後 30 分目に腫 瘍片および脳を採取し, 組織内濃度を HPLC で測定した。

統計解析: 多群間の比較は分散分析(ANOVA) で, 特定の 2 群間の比較は Tukey-Kramer's test および Student's t-test で行い, 危険率 $5 \%$ 以下を有意な差とした。

\footnotetext{
* 九州大学大学院薬学研究院臨床薬学講座薬物動態学分野 干 812-8582 福岡市東区馬出 3-1-1
} 


\section{【結 果】}

MLT の抗腫瘍効果は 07:00，01:00 投薬群 で認められ(07:00 P<.05, 01:00 $\mathrm{P}<.01), 19: 00$ 投薬群では腫瘍増殖抑制の傾向がみられたが, 13:00 投薬群の腫瘍推定重量は Saline 群と同 程度で, 抗腫瘍効果は認められなかった。

マウスの行動に与える影響については, 13:00 投薬群では投薬開始時から活動期の行 動量の低下が認められたのに対し，01:00 投 薬群では投薬を繰り返すことにより行動量が 低下した。

これらの機序として腫瘍細胞および SCN における MLT レセプター機能を解析した結 果, MLTレセプター結合量は 07:00, 13:00, 19:00 および 01:00 に採取した腫瘍細胞で有 意に異なることが明らかとなり $(\mathrm{P}<.05)$ ， 13:00 に最小値, 01:00 に最高值を示した. また, SCN のレセプター数は 13:00 と比較し て 01:00 に有意に高值を示し $(\mathrm{P}<.05)$, 親和性 に差は認められなかった。

一方，血中 MLT 濃度には投薬時刻による 差異が認められたが, 腫瘍および脳内 MLT 濃度には投薬時刻による差は認められなかっ た.

\section{【考察】}

今回の検討で，MLT の抗腫瘍効果は，投薬 時刻により異なることが明らかとなった。ま た, MLT の投薬により生体リズムが障害され る危険性が示唆され，さらにその程度が投薬
時刻により変化することが明らかとなった. 薬物の効果および毒性は，作用部位の薬物に 対する感受性と作用部位の薬物濃度により規 定される ${ }^{3)}$. MLT の抗腫瘍効果および生体リ ズム変容作用は, それぞれ標的組織である腫 瘍細胞やSCNに存在するMLTレセプターを 介し発揮される. 今回の検討で, MLT の作用 発現とレセプター発現量には対応が認められ， 投薬時刻により差が生じる機序として, 標的 組織における MLT レセプター発現量の日周 リズムが関与していることが示唆された.

以上の結果より, レセプター機能の日周リ ズムを考慮して投薬タイミングを設定するこ とでMLT の抗腫瘍効果を最大限に発揮させ, MLT 投薬による生体リズム障害を回避でき ることが明らかとなり, MLT 使用の際に投薬 時刻を考慮することの重要性が示唆された.

\section{【参考文献】}

1）大戸茂弘: 時計遺伝子と時間薬理学. 分子 精神医学 1(5):475-484 (2001).

2) Ohdo S, Koyanagi S, Suyama $\mathrm{H}$ et al:Changing the dosing schedule minimizes the disruptive effects of interferon on clock function. Nature Med 7:356-360 (2001). 3) Takane H, Ohdo S, Yamada T et al:Chronopharmacology of antitumor effect induced by interferon- $\beta$ in tumor-bearing mice. J Pharmacol Exp Ther 294:746-752 (2000). 